\title{
SELF-CONTROL AND SELF-REGULATION OF EMOTIONS IN THE STRUCTURE OF EMOTIONAL INTELLIGENCE
}

\section{Zaritskaya V. V., Falko N. M.}

\section{INTRODUCTION}

This section describes the approaches of scientists to the interpretation of the concepts of «self-control of emotions», "selfregulation of emotions», the meaning of these abilities to ensure adequate response and the environment, events, actions of individuals and others; the most important indicators by which it is possible to determine the level of development of self-control and self-regulation of emotions are highlighted; ways of overcoming difficulties for selfcontrol or self-regulation of emotions are shown, and how you can learn this. The problem of emotional self-control and self-regulation is one of the important psychological problems relevant to personal and professional growth. Significant psychological stress, particularly in professional activities related to the human-to-human relationship system, causes the development of occupational stress, mental alientation and disorganization of behaviour. One of the factors that do not contribute to the stabilization of the positive-emotional state of the individual is still the authoritarian nature of the educational process in educational institutions, when attention is focused only on the process of learning, skills, and there are no permanent active means of removing emotional stress, positive emotions ${ }^{1}$. Especially there is great influence of emotional stress on young professionals. It is a professional duty to make judicious decisions, to overcome irritation, despair, to contain anger ${ }^{2}$. In view of the above named, self-control and self-regulation of emotions are considered by us to be important components of emotional intelligence. Many scientists emphasize their

${ }^{1}$ Назарець Л.М. Емоційна регуляція пізнавальних процесів як чинник духовного становлення підлітків / Л.М. Назарець // Проблеми загальної та педагогічної психології : зб. наук. пр. Ін-ту психології ім. Г.С. Костюка АПН України / [за ред. С.Д. Максименка]. - К., 2007. - Т. IX. - Ч. 6. - С. 298-303.

2 Андреева И.Н. Когнитивные стратегии эмоциональной саморегуляции в педагогической деятельности / И.Н. Андреева // Вести БДПУ. - 2008. - № 4. - С. 31-35. 
importance. For example, R. Bar-On ${ }^{3}$ views the ability to control one's emotions as a manifestation of independence, as well as the ability to express feelings openly, be firm and defend the point of view as a manifestation of self-affirmation (assertiveness).

\section{Self-control of Emotions as a Psychological Phenomenon}

Self-control acts as the ability to control one's emotions. Fear of expressing emotions (seclusion, caution, etc.) or exaggerated manifestation of them (anger, anxiety, sadness) are always psychological and physiological processes. The physiological aspect is manifested in the acceleration or deceleration of of heart rate, blood pressure changes and hormonal balance disturbance - all this takes away a person's strength and inhibits potential. A person with a low level of self-control is not capable of holding back emotions (which may affect her emotional well-being), and is not capable of expressing them (which also has a bad effect on her well-being and emotional well-being of others). In each situation, you should be able to determine the optimal middle of emotions in accordance with existing events. In this regard, D. Goleman ${ }^{4}$ argues that self-control is an internal dialogue, an element of emotional intelligence that does not allow our feelings to dictate our will. It is self-control that gives clarity to the mind, empowers us with the energy that human beings need, and saves people from the effects of destructive emotions. People who are well able to self-control emotions are always cheerful, optimistic, able to set others up for a positive attitude to the phenomena or events in which they are currently involved. As emotions are usually transmitted from one person to another, it is extremely important to be able to control one's own emotions so as not to disrupt relationships with other people. If a person in a good mood is talking to a person characterized as conflicted, aggressive, the consequences of the conversation can have two aspects: the first - if the person responds to the aggression in the same way, then the conversation ends with increased irritation between the interlocutors; second - if a person does not respond to the pressure of aggression, then, remains in a positive

3 Андреева И.Н. Эмоциональный интеллект: исследование феномена / И.Н. Андреева // Вопросы психологии. - 2006. - № 3. - С. 78-86.

${ }^{4}$ Гоулман Д. Эмоциональное лидерство: Искусство управления людьми на основе эмоционального интеллекта / Дэниел Гоулман, Ричард Бояцис, Энни Макки. - М. : Альбина Бизнес Букс, 2007. - 301 с. 
mood, the aggressive individual has a chance to calm down or at least reduce irritation. Thus, it can be concluded that the ability to control their own emotions, even in adverse situations, contributes to maintaining optimism and positive mood. Self-control allows a person to be sincere, and such emotional transparency is not only the property of the person, especially the leader, but also an essential asset of the organization he heads.

Honesty in communication as unwavering openness in feelings, confidence in actions generates honour and honesty, and it inspires confidence in this person. For example, leaders who are given a high level of self-control, they allow a degree of sincerity that allows them to feel comfortable in terms of being open to people. In our view, this applies to any person, not just a leader, to maintain sincere, friendly relationships with others. D. Goleman self-control includes such abilities as: the ability to control his own emotions, openness, adaptability, the will to win, initiative, optimism. He characterizes his ability to control his emotions as being able to remain calm even in difficult or stressful situations; describes openness as a sincere expression of one's feelings and beliefs; adaptability - as the ability to respond flexibly and adapt to circumstances; the will to show victory by improving the quality of work, self-improvement and improvement of the work of those who work alongside; initiative as the ability to violate outdated rules or practices and make unconventional suggestions to improve work or solve a problem; optimism is the ability to find in any situation a favourable opportunity to solve it, not a threat, guided by the rule that all changes should be seen as changes for the better. Ye. Ilyin complements these abilities with the ability to use counterfacts aimed at reducing the significance of activities that cause emotional stress, which improves the emotional state of the person $^{5}$ and prevents the emergence of emotional exhaustion, which develops against the backdrop of emotional overload and can be exhausted by the failure of resources activities ${ }^{6}$.

The importance of self-control of emotions was also pointed out by P. Salovey and J. Mayer ${ }^{7}$, who argued that the accuracy of evaluation and expression of emotions is necessary because emotions

${ }^{5}$ Ильин Е.П. Эмоции и чувства / Е.П. Ильин. - СПб. : Питер, 2001. - С. 242-244.

${ }^{6}$ Ильин Е.П. Мотивация и мотивы / Е.П. Ильин. - СПб. : Питер, 2006. - 512 с.

7 Андреева И.Н. Эмоциональный интеллект: исследование феномена / И.Н. Андреева // Вопросы психологии. - 2006. - № 3. - С. 78-86. 
are a signal to a person about important events or their own needs, they affect their whole thought process, behaviour and help understand how to think and act more effectively using emotions. The level of selfcontrol of emotions depends on the nature of emotions, as they can be both desirable and undesirable. The over-expression of emotions, as well as their insufficiency, can disrupt activities or worsen relationships between people, which usually leads to emotional tension. There are some techniques that contribute to the removal of emotional stress, namely: the focus on individual technical details, tactical techniques, but not on the significance of the result; reducing the importance of the activity, its value, which will calm the anxious person a little; obtaining additional information that will reduce emotional tension; developing a fallback strategy; suspension of work for a certain period of time; physical discharge (walking, listening to music; doing other work, etc.); a smile that keeps you in the mood for negative feelings will improve your mood; activating the sense of humour because laughter reduces tension; muscle relaxation (relaxation), which is an element of autogenic training and is recommended for stress relief $^{8}$. Suppressing emotions can sometimes make it easier for a person, though sometimes more difficult, to endure pain or other unpleasant feelings. Controlling the expression of one's own emotions (expression) according to the research of psychologists is manifested in three forms: «inhibition», that is, an attempt to outwardly display one's emotional state; «masking», that is, the replacement of the expression of true emotions with other emotions; «simulation», that is, the expression of outward emotions that a person does not experience.

Research by I. Pereverzeyeva ${ }^{9}$ found that forms of expression of emotions depend on age. The older the person, the better she is able to choose the form of emotion in specific situations, provided that she was taught to control her own emotions, and if not taught, she can manifest them in adulthood regardless of the situation or the rules of etiquette. The following pattern was found: in persons with a predominance of positive emotions, no significant difference was

8 Психология: учебник для гуманитарных вузов / [под общ. ред. В.Н. Дружинина]. - СПб. : Питер, 2007. - 656 с.

9 Переверзева И.А. Проявление индивидуальных различий по эмоциональности в функции контроля за эмоциональной экспрессией / И.А. Переверзева // Вопросы психологии. - 1989. - № 1. - С. 113-117. 
found between the frequency of emotions and the frequency of expression of different emotions, which indicates the weakness of their control of their emotions. These people, as they experience the environment, so in most cases they manifest it. And people who are prone to experiencing negative emotions have a higher degree of control over emotional expression, at the expense of which they are able to «mask» their own negative emotions, replacing them with positive emotions that they do not experience. In persons with a strong tendency to experience negative emotions, firstly, a higher degree of control of the expression of both positive and negative emotions; secondly, negative emotions are more often experienced than expressed (ie, their expression is controlled in the form of «inhibition»); third, positive emotions, on the contrary, are more often expressed than experienced (ie, control of their expression is carried out in the form of «simulation»). This is due to the fact that the expression of positive emotions promotes communication and productive activities. Of particular importance in providing self-control over emotions, in particular, S. Yemelyanov ${ }^{10}$ attaches to the formation of an installation for constructive behaviour. He proposes to follow the three basic rules of self-control of emotions that are accessible to each person and do not require special training. The first rule of self-control is a calm reaction to the phenomena, processes or emotional actions of a partner. He calls this phenomenon conditionally emotional endurance, that is, the ability of a person to prevent exaggeration in the manifestation of negative emotional reactions to acute situations. The second rule of self-control is the rationalization of emotions, the exchange of the content of emotional experiences in the process of quiet communication. Compliance with this rule implies that when a partner is in a state of emotional commotion, they do not need to be in the mood to avoid entering this state themselves. To this end, one is asked to ask himself the following questions: "Why does this person behave like this?», «What are the motives of his or her behaviour?», "Is his or her behaviour related to the individual characteristics or for any other reason?» and others. Asking such questions and answering them, a person has a number of advantages over other people: firstly, in critical situations, people are forced to actively work consciousness

10 Емельянов С.М. Практикум по конфликтологии / С.М. Емельянов. - СПб. : Питер, 2001. - 400 с. 
and thus further protect themselves from emotional explosion; secondly, by his behaviour a person gives his interlocutor to express his emotions in full force; thirdly, the rationalization of emotions distracts the person from unnecessary and sometimes harmful information that can be disclosed by the interlocutor in the state of excitement; fourthly, when answering a question, a person solves an extremely important and difficult task that is looking for a reason and trying to understand the motives of such emotional state of the interlocutor. The third rule of self-control is to maintain high selfesteem as a basis for constructive behaviour, because one of the reasons for the undesirable emotional reactions of the interlocutors is often their underestimation. The inadequacy of emotional behaviour in this case is explained by one of the mechanisms of psychological protection which is known as regression. To exclude unwanted emotional reactions, it is necessary to maintain a high level of selfesteem in himself and in the interlocutor. The level of personality's ability to self-control determines the level of controlling of their emotions. In particular, I. Andreyeva defines self-control as the ability to control one's emotions, to distinguish them as a separate object, to adequately assess, publicize, control emotional expression (restraint). She emphasizes the importance of developing the ability to have adequate emotional expression, which is an important factor in physical and mental health, arguing that excessive restraint of emotions causes various illnesses. At the same time, uncontrolled emotional expression impedes interpersonal communication. Among the reasons for the difficulties in expressing emotions in accordance with the situation I. Andreyeva names, for example, the following: mastering the forms of expression of emotions that prevail in the family and immediate surroundings and are not the norm in society; lack of knowledge about the socially recognized forms of expression of emotions; fear of publicizing one's feelings associated with fear of condemning others; some birth factors, although the level of learning is still crucial. The basic steps of teaching self-control are offered by A. Bandura ${ }^{11}$. He argues that these steps are acceptable for both internal (psychological) and external (behavioural) self-control. In the context of our study, we characterize these steps in the self-control of

11 Хьелл Л. Теории личности / Л. Хьелл, Д. Зиглер. - 3-е изд. - СПб. : Питер, 2006. -607 c. 
emotions in terms of his social-cognitive theory of personality. The first step of self-control is to determine the exact form of expression of emotions in this situation. Unfortunately, this step is much more complicated than it might seem at first glance. It requires a thoughtful attitude to the situation. The second step is to collect the basic data, that is, to obtain information about the situation itself, the causes of its occurrence, the nature of the course, the peculiarities of the people involved in the situation. The third step is the development of an action program, ie the choice of a way to respond to the situation, the inclusion of emotional experience, self-reinforcement, self-order, taking into account the environment, etc. The fourth step is an agreement with yourself about the extent and nature of emotions in this situation, taking into account all the necessary factors. The fifth step is to accurately predict the end result of a particular emotion. Ultimately, emotional reactions should lead to a positive exit from the situation, and become the next step in developing the experience of adequate expression of emotions in the situation in which a person finds himself. The above steps of learning self-control are also a process of learning self-regulation of emotions. The process of learning, in particular, of social learning is presented in the theory of J. Rotter. At the heart of this theory is the prediction of human behaviour in difficult situations, which, of course, is accompanied by the manifestation of emotions. For behavioural prediction, the interaction of four variables must be analysed in detail: the potential for behaviour, the expectations, the value of reinforcement, and the psychological situation that the individual represents. Thus, the potential of behaviour consists of emotional reactions, motor reactions, cognition, verbal behaviour, nonverbal expression of behaviour, etc., that is, those types of human activity in response to a stimulus response that can be identified and measured in some way. J. Rotter refers expectation to the subjective likelihood that some reinforcement will occur as a result of specific behaviour. His conception of expectation clearly indicates that if in the past people have received reinforcements for their behaviour in this situation, they most often repeat this behaviour. The other behaviour of a person when they get into a situation for the first time. In this case, the expectation is based on the experience of the person in such situations. In fact, he argues that a stable expectation, generalized on the basis of past experience, really explains the stability of the individual. However, he emphasizes that expectations are not always 
true. Some people, for example, may have unrealistically high expectations of their success regardless of the situation. And others may be so insecure that they constantly underestimate their chances of success in this situation. In any case, if we are to accurately predict an individual's behaviour, then we should rely on his own subjective assessment of success and failure, not on the evaluation of someone else. It identifies two types of expectations: specific expectations that are specific to certain situations and generalized expectations that reflect the experience of different situations and can be used in many situations. Generalized expectations are also called the internalexternal locus of control, which is interpreted as a generalized expectation of the extent to which people control reinforcement in their lives. People with an external locus of control believe that their successes or failures are governed by external factors such as fate, luck, influential people and unforeseen forces of the environment. And people with an internal locus of control believe that successes and failures are determined by their own actions and abilities (internal, personal factors). Therefore, «internals» feel that they have a greater impact on reinforcement than people with an external orientation of the locus of control. People with a fuzzy orientation of the locus of control are between these two extremes. Given this, one can measure the locus of control over J. Rotter's methodology ${ }^{12}$. With this test, interns were found to be more than cautious externs, for example, to maintain or repair health, less likely to have psychological illnesses, and to adapt better. People are able to achieve greater success if they believe that their fate is in their own hands. These people are less influenced by other people, better able to control their own behaviour and that of others, more confident in solving problems than externalities, and therefore independent of others. The third component of behaviour is the value of reinforcement as the level by which one reinforcement is preferred over another. The value of reinforcement is based on previous experience, like expectations, it changes from situation to situation over time. According to J. Rotter theory, the value of reinforcement does not depend on expectation. For example, a student knows that good academic grades is of high value, and yet expectations of high grades may be low due to lack of ability or

12 Практикум по возрастной психологии : учеб пособ. / [под ред. Л.А. Головей, Е.Ф. Рыбалко]. - СПб. : Речь, 2006. - 688 с. 
activity. Therefore, the value of reinforcement is correlated with motivation, and expectations with cognitive processes. The fourth variable for predicting behaviour is a psychological situation from the perspective of the individual. Social situations are what they are represented by people. He points to the important role of the situational context and its influence on human behaviour and expresses the opinion that the set of key stimuli in a particular social situation causes the person to expect the results of behaviour is reinforcement. The interaction of man with the significant environment is the foundation of of J. Rotter's theory. He adheres to A. Bandura's opinion that personal factors and events of the environment in interaction best predict human behaviour. And the psychological situation should be considered alongside the expectation and value of reinforcement to predict any alternative behaviour. All four components of behaviour, according to J. Rotter, are related to human needs. In order to predict a person's response to a particular situation and their behaviour, six main categories of needs need to be considered: recognition status; protection - independence (confidence in protecting, for example, family members from certain troubles); domination (ability to influence other people); independence (ability to make decisions independently); love and affection (the need for a person to be loved and treated favourably); physical comfort (physical security, good health and more). All these categories of needs imply the presence of certain feelings, emotional states, which are accompanied by the realization of needs through behavioural manifestations. So, by the example of self-control of our own behaviour, we have proved that self-control of emotions is a control over our own emotions, because the emotional state determines the choice of behaviour at the moment.

\section{Self-regulation of Emotions as a Factor of Emotional Intelligence of Personality}

It is very important to be able to regulate the emotions that have arisen in order to choose a behaviour appropriate to the situation. The ability to regulate one's emotions has been called self-regulation in psychological science, although it should be noted that the concept of «self-regulation» is interpreted differently in different psychological studies. The wide range of differences is explained, first of all, by the different degree of commonality of the processes described in these concepts. In particular, V. Havrilkevich interprets the concept of «self- 
regulation» as an internal activity of the system aimed at bringing internal systemic phenomena to certain rules and norms, and «regulation of emotions» means the same, but it already assumes the presence of the subject of the regulatory process, which is personality, and the object of regulatory influences is emotional phenomena ${ }^{13}$. Selfcontrol is subject to self-regulation as one of its components along with processes such as self-programming and self-correction. On this basis, V. Havrilkevich concludes that in the process of self-regulation there are three components: self-programming, self-control and selfcorrection. L. Chunikhina notes that among the main approaches to explaining the essence of self-regulation in the scientific literature are the following ${ }^{14}$.

Self-regulation is a special level of activity programming based on prediction processes; managing a person's emotions, feelings, emotions; purposeful change of both individual psychophysiological functions and neuro-mental states as a whole; purposeful conscious choice of character and mode of action; «internal» regulation of the individual's own behavioural activity; interaction of external and internal in the behaviour and activity of the individual, etc. She argues that the ambiguity of the term "self-regulation» is conditioned, on the one hand, by multilevel construction, the multiplicity of aspects of study, and, on the other, by the double meaning of the root «self» (which indicates human activity, the ability to perform conscious «arbitrary» actions and so that processes can proceed as if "by themselves", spontaneously).

In modern research there are many types and levels of selfregulation that are the object of analysis and study: social, biological, physiological, psychological, conscious and unconscious, volitional, executive, direct and indirect, cognitive, personal, motivational, intellectual, emotional, reflective, hidden, rigid and flexible, individual and more.

13 Гаврилькевич В.К. Емоційна саморегуляція: систематизація базових понять на підставі їх семантико-етимологічного аналізу / В.К. Гаврилькевич // Актуальні проблеми психології / [за ред. акад. С.Д. Максименка]. - К. : Главник, 2008. - Т. Х. Ч. 5. - С. $108-115$.

14 Чунихина Л.В. Формирование способности к эмоциональной саморегуляции у будущих практических психологов в процессе профессиональной подготовки / Л.В. Чунихина // Практична психологія та соціальна робота. - 2004. - № 5. - С. 27-29. 
From a practical, applied point of view, it is important to realize that firstly self-regulation is a process of influencing one's own physiological and neuro-psychological state; secondly self-regulation is essentially dependent on a person's desire to manage his or her own emotions, feelings and emotions, and, as a consequence, behaviour; thirdly the ability to self-regulate is not given from birth, but develops in the process of life, that is, it is amenable to formation and improvement. This means that one can be taught to regulate one's own emotions so as not to translate them into a destructive plane. We must learn to do this as C. Izard ${ }^{15}$ points out to analyse the functions of a particular emotion at three levels: biological, motivational and social. The biological function of emotion is that the response of an organism to a particular stimulus directs the flow of blood and energy resources from the muscles of the internal organs to the muscles that are responsible for the movements, as is the case when experiencing emotions of anger, pain, fear, etc. The motivational function of emotion is that it strains and excites the person's perception, thinking and behaviour. The social function of emotion is expressed in the fact that the signal aspect of the vital system of human interaction with other people consists of a set of emotional manifestations. C. Izard emphasizes that any emotion performs a signal function as a whole, and as a signal plays an important role not only in the relations and communication between people, but also in the development of relationships between emotion and cognitive processes, resulting in the development of emotional intelligence in general. In addition, L. Chunikhina, argues that the level of self-regulation is the most striking indicator of emotional stability, which is extremely important, especially in professional activity, so to form this quality is one of the tasks in training a specialist.

The concept of «emotional resistance» in the scientific literature is also considered differently. From our point of view, the most generalized definition is given by O. Chernikova, who understands under emotional stability positive psychological quality, which is expressed in the fact that emotion reaches the optimum degree of intensity in responsible moments, characterized by stability of qualitative features, having stable orientation. We consider the set of tasks as an indicator of readiness to solve problems, especially since

${ }^{15}$ Изард К.Э. Психология эмоций / К.Э. Изард. - СПб. : Питер, 2007. - 464 с. 
this problem is most acute in the youth environment. As you know, this age is the most sensitive to the development of emotional stability, conscious self-control and self-regulation, because it is during this period that the most intense process of self-affirmation of young people among peers and adults. Due to the specifics of modern production, which places high demands on the emotional resources of young professionals, there is a need to study and develop emotional stability already at the stage of getting the profession.

A. Bandura presents his vision of the content of the concept of "self-regulation" on the example of self-regulation of behaviour in the context of social-cognitive theory of personality. With this concept he described the effect of self-esteem. Self-regulatory motives enhance behaviour through their motivational function. Self-regulation of behaviour, according to A. Bandura, involves three processes: the process of self-observation, self-esteem and self-response. Selfobservation (for example, the quality and speed of reactions) changes in a person for a number of reasons, depending on the type of activity, communication, emotional state at present. Self-esteem, as an element of self-regulation of behaviour, is considered in terms of conformity of behaviour to the norms that exist in a given society, that is, recognized standards. If it meets the standards, it is considered adequate and, if not, inadequate. A wide range of human behaviour is regulated through self-esteem reactions, expressed in the form of satisfaction with oneself, pride in one's success or dissatisfaction with oneself, selfcriticism. Self-criticism is considered a process of self-response. Other things being equal, positive self-esteem leads to a reassuring response, and negative self-esteem leads to a punitive response. From a socialcognitive point of view, people worry and condemn themselves when they violate behaviour. The excitement and condemnation of oneself pours into such a chain of events: misconduct - internal discomfort self-punishment - relief. Such a chain of events ends not only the excitement of misconduct and its possible social consequences, but also seeks to win back the approval of others. Judging themselves for their actions, people no longer suffer for the past. Therefore, selfpunishment is the responsibility for the actions that you have committed. It can also have negative consequences: it can lead to depression, alcoholism, drug addiction, that somehow it is not so difficult to tolerate failures, non-adaptability. This may be the result of too strict internal norms of self-esteem. To prevent such phenomena, 
the concept of «self-efficacy» is introduced as the ability of a person to become aware of their abilities and to build behaviour in accordance with a situation or specific task. This is an important ability of a person, because how a person evaluates his or her own performance determines for him the expansion or narrowing of his choice of activities, the efforts that he will have to make to overcome obstacles, the persistence that will solve certain problems. Thus, self-efficacy affects behaviour forms, motivation, behaviour, and emotions. People who are aware of their self-efficacy make more effort to accomplish complex tasks than people who have doubts about their capabilities. High self-efficacy associated with the expectation of success usually results in positive results and promotes self-esteem. Self-efficacy can occur in four ways or combinations of these: the ability to build behaviour, mediate experience, verbal beliefs, emotional rise. The most important source of self-efficacy is past experience that helps to build appropriate behaviour and emotional state of the person. Although not as effective as one's own experience, indirect experience (the experience gained through observing other people) also helps to build some behaviour according to the situation. For example, students who are afraid to ask a teacher a question at a lecture where many students, as other students ask a question, receive a teacher's answer without negative consequences for the students, become bolder and begin to ask the lecturer at further lectures. At the same time, when the teacher has a negative reaction to students' questions, other students will not ask them. Self-efficacy can be enhanced by the fact that someone has been able to convince her of her high capabilities, ability to perform certain actions. A. Bandura hypothesized that the power of verbal persuasion is limited by the conscious status and authority of the persuasive. Given that people align self-efficacy with emotional distress in stressful or threatening situations, any way that lowers excitement will increase the prognosis of efficacy. A man who feels insecure, such as communicating with a woman, may feel his heart begin to beat and his palms become wet when he calls a woman making appointments. If you attribute these physiological reactions to excitement, you can decide that he is nervous, but if he is calm, dialing a number, then we can say that he is more effective than he had anticipated. Thus, as shown in this example, people who are not stressed and emotionally calm are more likely to succeed. The effectiveness of any event, the manifestation of any emotion is 
determined primarily by the ability of a person to increase conscious self-efficacy. A person's diligence and perseverance in the face of obstacles or setbacks is governed by an expectation of effectiveness. Increased expectations of personal effectiveness push the person to take various steps that are important for improving psychosocial functioning. Self-efficacy is a cognitive mechanism that combats various emotional states such as excitement, fear, anxiety. This mechanism is used even in medicine as a practical treatment aimed at assuming a level of awareness of self-efficacy. Based on the analysis of numerous studies, A. Bandura argues that changes in expectations of efficiency contribute to changes in a person's life style, so it can be considered that the development of self-efficacy is a self-regulating change, which makes a person more emotionally balanced and rational.

M. Vasilyev ${ }^{16}$ proves that the reaction to certain phenomena or events can be adjusted, changed, even if they have become a habit, although there are different opinions about this. He proposes, first of all, to force himself to act not as usual, but as the situation requires. This reaction is called controlled consciousness, as a result of human behaviour and the expression of emotions will be adequate to the situation. The difficulty is that when a situation, for example, is conflictual, a person significantly reduces the ability to consciously regulate behaviour, and it often acts out of habit. Despite of this, psychotherapy and psychotechnics are in search of methods by which one can move away from stereotypes of emotional reaction and consciously produce self-regulation of emotions. M. Vasilyev identifies the stages in the flow of emotions and proposes appropriate methods of self-regulation. The first stage is the process of perceiving an event, forming a psychological image and symbolizing it in the mind. The main method is to change the focus of the event perception process. The second stage is the emotional evaluation of the event. The main method is to emotionally evaluate an event from another person's perspective. The third stage is the internal emotional experience. The basic method is to force yourself with the will to calm down. The fourth stage is an external behavioural response. The main method is to try to bring the emotion into the situation as close as possible to show others. Stage five is the emotional consequences of the situation. The

${ }^{16}$ Васильев Н.Н. Тренинг преодоления конфликтов / Н.Н. Васильев. - СПб. : Речь, 2007. - 174 c. 
main method is to force yourself to show calm and outwardly positive emotional state. It should be noted that the above methods of selfregulation are not always effective from the first time. Human efforts are gradually increasing. This phenomenon is due to both biological and psychological characteristics of man. Speaking in the language of neuroscience, the processes of excitation is inhibition obey the mechanism of «assimilation of rhythm», discovered by A. Ukhtomsky and confirmed by studies of L. Okhnyanska, V. Mishchin, L. Gracheva ${ }^{17}$, who note that the more stable the habit of responding to a certain event, the more difficult it is for a person to stay, though it all depends on a person's ability to move beyond mental discomfort. L. Gracheva proves that there are types of personality, which is characteristic of a wide range of rhythms. Such people behave calmly even in the most acute situations, although this does not mean that they do not emotionally perceive the situation, they simply do not get hung up on negative emotions, and easily switch, for example, a stressful state of calm, without waiting for the emergence of stable nerve connections. and increased emotional tension. She argues that the ability to self-regulate emotions can be developed to the level of habit on the principle of training the processes of excitation inhibition.

A. Gretsov ${ }^{18}$ offers his way of developing the capacity for selfregulation of emotions. He believes that the process of self-regulation of emotions, for example, in the case of manipulative influence, includes: recognition of the fact of manipulative influence; maintaining emotional calm (manipulators, as a rule, «catch» their victim precisely on emotions); systematic defence of their interests or a calm reaction to the event, the situation, despite the emotions and behaviour of the manipulator. In each offered exercise he proved that by following these components while performing a cycle of certain exercises, one can develop the ability to resist any negative influences by developing the ability to self-regulate emotions. These exercises can be aimed at: a person looking at his or her emotional state with «another's eyes»; internally removed from the situation; adjusted her emotional state according to the situation; adjusted the intonation of speech, facial

17 Грачева Л.В. Эмоциональный тренинг: искусство властвовать собой. Самоиндукция эмоций, упражнения Л.В. Грачева. - СПб. : Речь, 2004. - 120 с.

${ }^{18}$ Грецов А. Тренинг уверенного поведения для старшеклассников и студентов / А. Грецов. - СПб. : Питер, 2008. - 192 с. 
expressions, movements; constructed an adequate response to any unusual event, whether explicit or imagined; restrained emotions (laughter, anxiety, anger and more); calmly reacted to unpleasant information about himself, about friends and more.

Professionals often encounter manipulation by professionals. The manipulator for the realization of the plans imperceptibly for others influences another person. These covert actions (conversations are also actions) excite a person to perform the actions required by the manipulator, and at the same time to think that he or she independently controls his behaviour. N. Starostina ${ }^{1}$ believes that you can protect yourself from manipulation only if you know the mechanism of constructing manipulations, because understanding them is the way that will protect the person from the manipulator. It offers the following protection scheme: knowledge (maximum manipulator and situation information possible), experience (repeated use of knowledge in practice in different situations), awareness (what, how and why everything happens, how I behave, how others behave in this situation.), managing your feelings and emotions, controlling your feelings and emotions. However, N. Starostina ${ }^{19}$ notes that manipulation is not only negative but also positive. Its positive value, for example, in professional activity, when considering it give as a means of managing certain processes (pedagogical, therapeutic, psychological) in order to influence the human consciousness to improve its behaviour, health, mood, relationships with other people. Finally, according to researchers, ability to self-regulate emotions provides not only good mood, but also a positive attitude to yourself, because, as M. Bublichenko ${ }^{20}$ notes, chronic bad mood, internal emotional discomfort (aggression, depression, irritation, etc.) at a subconscious level leads to various disorders in the body and, weakens the immunity, causes the development of various neuroses and more. Thus, by developing selfregulation of emotions, the individual not only maintains emotional rest, but also their own health.

19 Старостина Н.В. Мастер-класс по защите от манипуляторов, или Примерь корону на себя / Н.В. Старостина. - Ростов н/Д : Феникс, 2008. - 282 с.

20 Бубличенко М.М. Научись общаться! - 2: руководство для хорошего собеседника / М.М. Бубличенко. - Ростов н/Д : Феникс, 2008. - 220 с 


\section{CONCLUSIONS}

Analysing different approaches of scientists to the interpretation of the essence of self-control and self-regulation of emotions; to the importance of these abilities for adequate response to the environment, events, actions of individuals; to the difficulties that accompany the process of mastering them, and ways to overcome them, as well as possible ways of mastering these abilities in the structure of emotional intelligence we offer, are the most important, in our opinion, indicators, the presence of which makes it possible to determine the level of development of self-control and self-regulation of emotions. These are indicators such as: the ability to restrain emotions; ability to express emotions according to the situation; the ability to remain calm in difficult situations; the ability to control their emotions; the ability to regulate the expression of their own emotions. The choice of such indicators allows us to say that the person who mastered them will be characterized by a high level of development of emotional intelligence, because it will act reasonably and carefully in accordance with the situation, which will ensure successful communication with others and high efficiency in professional activity. Self-control is seen as control over oneself, over one's emotional state, as an internal dialogue between emotions and the mind, which does not allow our feelings to dictate our will, but leads to the expression of emotions to the extent required in a particular situation. The ability to control one's emotions even under adverse conditions helps one to maintain optimism, positive mood, to show sincerity in communication, openness in feelings, confidence in actions that causes trust in that person around. Self-control includes the following abilities: the ability to control one's emotions; openness; adaptability; will, initiative, optimism. Selfcontrol of emotions is manifested in three forms: «inhibition» (attempting not to manifest their emotional state externally); «masking» (replacement of true emotions by others); «simulation» (expressions of outward emotions that a person does not actually experience). There are three important rules for ensuring a certain level of self-control: calm response to the situation; rationalization of emotions, exchange of the content of emotional experiences in the process of quiet communication; maintaining high self-esteem as an indicator of constructive behaviour in a particular situation. On the way to self-control according to a specific situation, people experience some difficulties. Among the main reasons for a person's inability to 
express emotions in an adequate situation, scientists call the following: assimilation of norms of expression of emotions in the family, which are not the norm in society; lack of knowledge about the norms of expression of emotions in society; fear of expressing their emotions related to fear of condemning others; individual congenital factors. Self-control of emotions can be taught to a person, and there are five basic steps to master the art of self-control: determining the exact form of expression of emotions in this situation; obtaining information about the situation itself; choosing a way to respond to a given situation; an agreement with himself about the extent and nature of the expression of emotions; predict the end result as accurately as possible. The process of learning the self-control of emotions is accompanied by a certain behaviour of a person towards other people in a particular situation. In order to predict behaviour appropriate to the situation, it is proposed (J. Rotter) to analyse the interaction of four variables: the potential of behaviour; expectation; the value of reinforcement; the psychological situation that the individual represents. Self-regulation of emotions is studied and researched by many scholars as an important component of emotional intelligence and is viewed as an internal dialogue between emotions and the mind, which induces the expression of emotions to the extent required in a particular situation. Self-regulation of emotions determines a certain human behaviour, which includes three processes: the process of self-observation, selfesteem and self-response. Specific ways to build an experience of selfregulation of emotions are exercise, social training, play methods and more which not only provides emotional comfort, but also promotes health. We have identified the most important indicators that can determine the level of development of self-control and self-regulation of emotions: the ability to restrain emotions; ability to express emotions according to the situation; the ability to remain calm in difficult situations; the ability to control their emotions; the ability to regulate one's emotions.

\section{SUMMARY}

The concept "emotion self-control" is revealed; scientists' approaches to ground it are analyzed; the forms of emotion self-control manifestation are shown; possible ways to master the art of emotion self-control are emphasized.

The concept of "emotion self-regulation" is revealed in this section; the significance of a person's ability to control emotions by 
herself is grounded; scientists' approaches to state the importance of the phenomenon within the structure of the emotional intelligence as well as ways to master the art of control emotions by oneself or with the help of others are given.

\section{REFERENCES}

1. Назарець Л.М. Емоційна регуляція пізнавальних процесів як чинник духовного становлення підлітків / Л.М. Назарець // Проблеми загальної та педагогічної психології : зб. наук. пр. Ін-ту психології ім. Г.С. Костюка АПН України / [за ред. С.Д. Максименка]. - К., 2007. - Т. ІХ. - Ч. 6. - С. 298-303.

2. Андреева И.Н. Когнитивные стратегии эмоциональной саморегуляции в педагогической деятельности / И.Н. Андреева // Вести БДПУ. - 2008. - № 4. - С. 31-35.

3. Андреева И.Н. Эмоциональный интеллект: исследование феномена / И.Н. Андреева // Вопросы психологии. - 2006. - № 3. C. $78-86$.

4. Гоулман Д. Эмоциональное лидерство: Искусство управления людьми на основе эмоционального интеллекта / Дэниел Гоулман, Ричард Бояцис, Энни Макки. - М. : Альбина Бизнес Букс, 2007. - 301 с.

5. Ильин Е.П. Эмоции и чувства / Е.П. Ильин. - СПб. : Питер, 2001. - C. 242-244.

6. Ильин Е.П. Мотивация и мотивы / Е.П. Ильин. - СПб. : Питер, 2006. - 512 с.

7. Андреева И.Н. Эмоциональный интеллект: исследование феномена / И.Н. Андреева // Вопросы психологии. - 2006. - № 3. C. $78-86$.

8. Психология : учебник для гуманитарных вузов / [под общ. ред. В.Н. Дружинина]. - СПб. : Питер, 2007. - 656 с.

9. Переверзева И.А. Проявление индивидуальных различий по эмоциональности в функции контроля за эмоциональной экспрессией / И.А. Переверзева // Вопросы психологии. - 1989. № $1 .-$ C. 113-117.

10. Емельянов C.M. Практикум по конфликтологии / С.М. Емельянов. - СПб. : Питер, 2001. - 400 с.

11. Хьелл Л. Теории личности / Л. Хьелл, Д. Зиглер. 3-е изд. - СПб. : Питер, 2006. - 607 с.

12. Практикум по возрастной психологии : учеб пособ. / [под ред. Л.А. Головей, Е.Ф. Рыбалко]. - СПб. : Речь, 2006. - 688 с.

13. Гаврилькевич В.К. Емоційна саморегуляція: систематизація базових понять на підставі їх семантико-етимоло- 
гічного аналізу / В.К. Гаврилькевич // Актуальні проблеми психології / [за ред. акад. С.Д. Максименка]. - К. : Главник, 2008. - Т. Х. - Ч. 5. - С. 108-115.

14. Чунихина Л.В. Формирование способности к эмоциональной саморегуляции у будущих практических психологов в процессе профессиональной подготовки / Л.В. Чунихина // Практична психологія та соціальна робота. 2004. - № 5. - C. 27-29.

15. Изард К.Э. Психология эмоций / К.Э. Изард. - СПб. : Питер, 2007. - 464 с.

16. Васильев Н.Н. Тренинг преодоления конфликтов / Н.Н. Васильев. - СПб. : Речь, 2007. - 174 с.

17. Грачева Л.В. Эмоциональный тренинг: искусство властвовать собой. Самоиндукция эмоций, упражнения актерского тренинга, исследования / Л.В. Грачева. - СПб. : Речь, 2004. $120 \mathrm{c}$.

18. Грецов А. Тренинг уверенного поведения для старшеклассников и студентов / А. Грецов. - СПб. : Питер, 2008. - 192 с.

19. Старостина Н.В. Мастер-класс по защите от манипуляторов, или Примерь корону на себя / Н.В. Старостина. Ростов н/Д : Феникс, 2008. - 282 с.

20. Бубличенко М.М. Научись общаться! - 2: руководство для хорошего собеседника / М.М. Бубличенко. - Ростов н/Д : Феникс, 2008. - 220 с.

\section{Information about the author:} Zarytska V. V.

Doctor of Psychological Sciences, Professor, Head of the Department of Practical Psychology, Classic Private University 70b, Zhukovsky str., Zaporizhzhya, 69002, Ukraine

Falko N. M.

$\mathrm{PhD}$ in Psychology, Associate Professor, Head of the Department of Psychology, Bogdan Khmelnitsky Melitopol State Pedagogical University 